\title{
DYNAMIC MULTIREGIONAL MODEL OF LABOUR MIGRATION: CONSTRUCTION AND REALIZATION ${ }^{1}$
}

This paper presents a dynamic multiregional model of labor migration in continuous time within the framework of the neoclassical economics. The model can predict the dynamics of migration flows as well as the dynamics of economic effects of migration simultaneously for host regions and source countries. Thanks to liberalization of the migratory legislation of the Russian Federation in 2007, the model can be used for Russian regions and CIS states, which citizens were granted entry without a visa and a simplified procedure of employment in Russia. Employing the model to statistical data, forecast trajectories of migration flows to Russian regions from CIS states have been received for the period since 2010 to 2016. The predicted migration looks quite realistic and has important policy consequences. In particular, these findings can be used for developing work permit quotas.

Keywords: labor migration, forecast, neoclassical theory, economic effects, dynamic modeling

\section{Introduction}

Increasing of mobility of the population is characteristic of the current period. Multinational migration, which is to say, free will or forced displacement of people through the state borders is assuming the character of universal phenomena.

The countries of western democracy in virtue of liberal and democratic traditions, high living standards and economic development, a guarantee of the rights and freedoms of a person undergo specific migration pressure. For many of these states, the immigration became a significant indicator of real adherence to the values of the political and economic liberalism assuming distribution of the civil, political and social rights to each member of society, creation and maintenance of rather free markets [18, page 6].

The resolute step towards liberalization of Migration Policy was as well made in Russia, in January 2007. The changes induced into the migration legislation of the Russian Federation consist in strong simplification of the rules of registration of foreign citizens according to place of temporary residence, and also an order of their employment. Basic changes in the migration legislation are briefly presented in table 1 .

In consequence of the changes included into the migration legislation of the Russian Federation (tab. 1), the registration procedure for the citizens of

\footnotetext{
${ }^{1}$ Work is performed within the framework of common projects with Far East Branch of the Russian Academy of Science (№12C-7-1001 «Socio-economic development of region: forecasting and optimum control»).
}

CIS states with whom Russia has regulations of visafree entry was replaced with the procedure of the migration registration, and its character is changed from permissive to notifying. Authorization procedure for temporary stay and permission for work in Russia is essentially simplified for the specified citizens. Labor migrants from CIS states have got more free access in the Russian labor market, arranging permission for work independently and gaining the right of change of an employer within a region where this permission was received. At the same time, sanctions against the employers breaking rules of hiring of foreign workers are made more rigorous.

Although the purposes of a new course of the Russia migration policy consists in the arrangement of conditions for providing the Russian labor market with legal foreign labor from the states which are historically close to Russia, and in expansion of channels of legal employment of foreign labors, the problem of illegal migration continues to be relevant for Russia as much, as in the countries of the western democracy. According to estimates of experts, Russia is the second outman of informal immigrants and the first according their part in a total number of foreign citizens (tab. 2). However on the Russian Federation territory illegal labor migrants are located non-uniformly that is caused by strong differentiation of level of socio-economic development of Russia regions [4, 10].

In the process of increasing migratory load, to control migration is more complicated from year to year. In turn the increase of number illegal migrants promotes an aggravation of a variety of risks 
Migration control in Russia before and after 2007

\begin{tabular}{|c|c|}
\hline Old order & Modern order \\
\hline \multicolumn{2}{|c|}{ Registration according to the place of temporary residence / migration registration ( all of the immigrants) } \\
\hline Permissive & Notifying \\
\hline According to militia permission & Upon notification of host party. Permission is not required \\
\hline According to address of residential accommodation & $\begin{array}{l}\text { According to address of residential accommodation or office } \\
\text { address, intermediary one (and others) of organization }\end{array}$ \\
\hline Registraion in militia & $\begin{array}{l}\text { Delivery of notification to the Federal migration service or } \\
\text { sending it by mail }\end{array}$ \\
\hline $\begin{array}{l}\text { A complex procedure demanding: } \\
\text { - recorded in writing the agreement of permanently residing } \\
\text { in the rented place and their collective corporal appearance } \\
\text { with a migrant in militia; } \\
\text { - abidance by standard per capita of living space (in some } \\
\text { regions according to the local legislation) }\end{array}$ & $\begin{array}{l}\text { A simple procedure only assuming the search of a host party } \\
\text { by the migrant and sending of the notification. }\end{array}$ \\
\hline \multicolumn{2}{|c|}{ Permission for work (visa-free immigrants) } \\
\hline Permit for employment of migrant is given to the employer & $\begin{array}{l}\text { Permission for work (the labor card) is received personally by } \\
\text { migrant. An employer notifies migratory service on hiring of } \\
\text { foreign worker }\end{array}$ \\
\hline Long multilink procedure & A simple procedure \\
\hline \multicolumn{2}{|c|}{ Quotas } \\
\hline Only for visa migrants & Separately for visa and visa-free migrants \\
\hline
\end{tabular}

Source: [7, c. 117].

Table 2

Population estimate of illegal immigrants

\begin{tabular}{|l|c|c|c|}
\hline \multicolumn{1}{|c|}{ Country } & $\begin{array}{c}\text { Thousands } \\
\text { of persons }\end{array}$ & $\begin{array}{c}\text { in \% to a total number } \\
\text { of foreign citizens }\end{array}$ & Year \\
\hline USA & 12000 & 32,4 & 2008 \\
\hline Russia & 4500 & 60,0 & 2008 \\
\hline Great Britain & 725 & 11,1 & 2007 \\
\hline Italy & 650 & 22,1 & 2008 \\
\hline Spain & 570 & 10,9 & 2008 \\
\hline Germany & 500 & 7,4 & 2005 \\
\hline Greece & 250 & 43,8 & 2007 \\
\hline Austria & 100 & 10,8 & 2003 \\
\hline
\end{tabular}

Source: based on $[7,17]$.

and threats, including the development of shadow economy [1].

Under current conditions the search of new forms of political regulation of the processes of international migration predetermines development by the governments of strategies (political programs, projects, anti-crisis stock items), focused on the regulation of migration flows and prevention of illegal migration. Elaboration of such strategy should be based on scientifically proven estimates of the current and prospective number of migrants with emphasis of its unregistered part. As a methodical basis for receiving these estimates, the dynamic multiregional model of labour migration, allowing investigating effects of liberalization of the migration legislation is offered.

\section{Theoretical basis of the research}

Liberal or cosmopolitan model of development is focused on general democratic values, which in the western liberal tradition associate with principles of market economy. This model is based on a paradigm of human rights it approves a priority of human rights over the rights of the citizens. The right to free movement is one of the fundamental human rights in a democratic society [5] and, therefore, hypothetically (in "pure" liberal model) it should prevail over separation of rights on the principle of citizenship (non citizenship), in other words theoretically all men and women irrespective of existence of citizenship of one or another country should possess this right. The liberal model of development assumes elimination of all obstacles for mobility of migrants.

Free migratory movements are included into the economic composition of the neoclassical theory proceed on the basis that they generate are a source of redistribution of factors of production between the countries in the conditions of a common market, i.e. redeployment of labour and related to it - movements of capitals and goods. According to neoclassical economics, migration is caused by a difference in wage levels between the countries, due to the difference in labor inputs on the capital between the countries. The wage differential will stimulate workers from countries of low wages to 
move to countries with a high salary while investing capital, including the human capital [6] essential for the creation of the expected income, will flow into the country with low wages. This process will proceed until the wage-rate difference between the countries is more than costs of labor moving.

Neoclassical economics is based on a principle of rational behavior of an employee. However in real life the possibilities of rational decision are limited. A laborer, making a decision on the need of migration and choosing a country of destination, faces a problem of incomplete information on conditions of a labor market and residence in other countries. The solution of this problem is promoted by migratory networks, which are understood as a set of interpersonal communications that connect migrants, the former migrants and not migrants among themselves by the medium of relatives, friendship and common social origin [24]. On the one hand, migratory networks help to spread information on living conditions in the different countries, help with employment and often insure employment. On the other hand, at achievement by migratory networks of a certain level of development, the migration becomes a self-maintained process. Here, again negative consequences of the existence of migratory networks start to predominate. Enclaves develop with their culture, rules and living conditions on the territory of the country. For the most part of migrants, already the need to study host country language, to try to adapt to new living conditions are absented. Thus, the migratory network starts to promote the inflow of migrants which national economy of reception does not need.

\section{Approaches to migratory modeling}

At the present time, the development of models of migration within a framework of neoclassical economics is actively conducted. Striyelkovski V. and Turnovets F. have developed a model for two countries, allowing assessing tendency of the rational individual to migrate on the basis of comparison of an expected income to migratory expenses [11]. In the offered model of Batishcheva G., except the listed factors, the rational individual also considers the probability of employment in an accepting region [3, pages 9-11]. At the same time, the presented models are mainly intended for description of the behavior of certain rational migrants and do not allow to receive a prediction of migration flows. As advantage of the latest model, it is necessary to point out, in this model is considered, that with an inflow of migrants, the offer on a labor market will grow, reducing the probability of employment in the accepting region. Accordingly, the model of Batishcheva G. considers the influence of migration on a labor market of an accepting region that is one of the economic effects of migration. According to our opinion, modeling of migration flows should be carried out in respect of these effects; it is crucial for departure country, and destination of migrants [14-16, 19-23].

As distinct from considered above models, the dynamic multiregional model of labor migration developed by us allows to predict at the same time both the migration and its economic effects. Besides, the considered models are constructed for two regions, one of which is the region of leaving, another the region of arrival; in the earlier version of our model [8] we consider one host regions and some source countries while in the new version of our model, potential migrants from several regions of origin, at making a decision on migration consider some potential regions of appointment. Such multiregional modeling allows predicting supplantation by migrants from "the poorer" countries, ready to work for smaller wages, other migrants, which, in turn can make the decision on return migration or choose other source countries.

\section{Dynamic multiregional model of labour migration}

The dynamic multiregional model of labour migration is constructed in continuous time within the framework of the neoclassical economics. Consider $n$ as host regions and $m$ as source countries of migrants in which all obstacles for mobility of labor force are eliminated. The number of migrants from $i$ country of origin into host regions of $j$ at the moment of time of $t$ are defined as $x_{i j}(t)$.

A rational individual makes a decision on migration from a source country of $i$ to host region of $j$ on the basis of comparison of its characterizing levels of wage ( $w_{i}$ and $w_{j}$ respectively). This decision will be positive if an expected income is positive according to a wage gap in a country of origin and a host region region of appointment of the migrant, i. e. $w_{j}-w_{i}>0$.

As a result of inflow of migrants $x_{j}(t)=$ $=\sum_{i=1}^{m} x_{i j}(t)$ from $\mathrm{m}$ source countries into host regions of $j$, the offer on a labor market will grow leading decreasing the probability of employment of a migrant of $p_{j}$. This probability is defined on the 
basis of assumptions that prior to the beginning of the migration process in host regions of $j$ number of workplaces equal to sum of volume of employment $E_{j}$ and number of vacant positions of $V_{j}$, but a number of job applicant equal to sum of volume of employment of $E_{j}$ and number of the unemployed of $U_{j}$ according to formula (1):

$$
p_{j}\left(x_{j}(t)\right)=\frac{E_{j}+V_{j}}{E_{j}+U_{j}+x_{j}(t)} .
$$

In turn, decrease of the probability of employment of a migrant will lead to competition growth on a labor market, resulting in decreasing the wage level of migrants in host regions of $j$ according to function (2):

$$
w_{j}\left(x_{j}(t)\right)=w_{j_{-} a v} p_{j}\left(x_{j}(t)\right),
$$

where $w_{j a v}$ - is an average salary of migrants in host regions of $j$.

In turn, as a result of outflow of migrants $x_{i}(t)=\sum_{j=1}^{n} x_{i j}(t)$ from $i$ source country into $n$ host region, on the contrary, will occur the decrease in supply of labor force on a labor market, leading to growth of wage level

$$
w_{i}\left(x_{i}(t)\right)=w_{i_{-} a v}\left(\frac{E_{i}+V_{i}}{E_{i}+U_{i}-x_{i}(t)}\right),
$$

where $w_{i a v}$ - is an average salary in $i$ country of origin; $E_{i}$ - numbers employed in $i$ host country; $V_{i}$ - number of the vacant positions in $i$ source country; $U_{i}$ - number of the unemployed in $i$ host country. Taking into account a process of level alignment of wage in $i$ source country and $j$ host region, decision-making process on migration is represented as follows:

1) $w_{j}\left(x_{j}(t)\right)-w_{i}\left(x_{i}(t)\right)>0$ - making a decision on migration from $i$ country into $j$;

2) $w_{j}\left(x_{j}(t)\right)-w_{i}\left(x_{i}(t)\right)<0$ - making a decision on returnable migration into $i$ country or moving to another $k \neq j$ host region for which the following condition is satisfied $w_{k}\left(x_{k}(t)\right)-w_{i}\left(x_{i}(t)\right)>0$.

At making a decision on migration, a rational individual will not only seek to maximize expected income, but also to minimize migratory expenses, including direct costs of resettlement. Under otherwise equal conditions $n$ individual chooses from a set of potential regions of migration the one, which is closer. The model of the influence of this factor on decision-making about migration reflects an $r_{i j}$ indicator (distance from a capital of $i$ source country to a $j$ regional host center).
Migratory networks which support the migration of nationals is a crucial institute of self-regulation of migratory processes. Development of these networks directly depends on a number of the migrants who have earlier arrived to the $j$ region of attraction from the same $i$ source country, for this reason in our model the influence of migratory networks on decision-making about migration reflects an indicator: $x_{i j}(t)$.

Taking into account that population outflow from the $i$ source country is limited by quantity of its potential migrants of $M_{i}$, the flows of labor migrants from an $i$ country of departure to a $j$ host region is described by the differential equation (4):

$$
\begin{aligned}
\frac{d x_{i j}(t)}{d t}= & \alpha \frac{1}{r_{i j}} x_{i j}(t)\left(M_{i}-\sum_{j=1}^{n} x_{i j}(t)\right) \times \\
& \times\left(w_{j}\left(x_{j}(t)\right)-w_{i}\left(x_{i}(t)\right)\right),
\end{aligned}
$$

where $\alpha$ - the calibration factor reflecting the influence of unrecorded factors in the model, mainly - not economic, on a tendency to migration.

The described model has been realized in the MatLab 7.10.0 program (R2010a).

\section{Data}

Model approbation on Russia regions and CIS states demand a data bulk. Data for Russia regions on quantity of labor migrants, a monthly average wage, a number of the employed and the unemployed were taken from publications of Federal state statistic service. [12]. Data for CIS states on average monthly wage, a number of the employed, and the unemployed were taken from sources of Interstate statistical committee CIS [9]. Number of potential migrants was defined on the basis of the results of a public opinion poll, which was carried out by Gallup in 12 Post-Soviet countries [13].

As source countries of migrants Tajikistan, Uzbekistan, Kyrgyzstan, Kazakhstan, Armenia, Azerbaijan and Ukraine were chosen. In 2007-2010, $60-70 \%$ from a total number of labor migrants in Russia (tab. 3) were from these countries (tab. 3).

As regions of attraction we consider Moscow, St. Petersburg and the Sverdlovsk region in which 35$45 \%$ of a total number of labor migrants in Russia are concentrated (see tab. 4).

\section{Calibration of data}

The model was calibrated according to data for the period since 2006 to 2008 . The affected period 
Composition of labor migrants in Russia

\begin{tabular}{|l|c|c|c|c|c|c|c|c|}
\hline \multirow{2}{*}{ Country } & \multicolumn{2}{|c|}{$\mathbf{2 0 0 6}$} & \multicolumn{2}{c|}{$\mathbf{2 0 0 7}$} & \multicolumn{2}{c|}{$\mathbf{2 0 0 8}$} & \multicolumn{2}{c|}{$\mathbf{2 0 1 0}$} \\
\cline { 2 - 9 } & $\mathbf{1 0 0 0}$ persons & $\mathbf{\%}$ & $\mathbf{1 0 0 0}$ persons & $\mathbf{\%}$ & $\mathbf{1 0 0 0}$ persons & $\mathbf{\%}$ & $\mathbf{1 0 0 0}$ persons & \% \\
\hline Azerbaijan & 28,3 & 2,8 & 57,6 & 3,4 & 76,3 & 3,1 & 40,3 & 2,5 \\
\hline Armenia & 39,8 & 3,9 & 73,4 & 4,3 & 100,1 & 4,1 & 59,8 & 3,6 \\
\hline Kazakhstan & 5,0 & 0,5 & 7,6 & 0,4 & 10,4 & 0,4 & 8,3 & 0,5 \\
\hline Kyrgyzstan & 33,0 & 3,3 & 109,6 & 6,4 & 184,6 & 7,6 & 117,7 & 7,2 \\
\hline Tajikistan & 98,7 & 9,7 & 250,2 & 14,6 & 391,4 & 16,1 & 268,6 & 16,4 \\
\hline Uzbekistan & 105,1 & 10,4 & 344,6 & 20,1 & 642,7 & 26,5 & 511,5 & 31,2 \\
\hline Ukraine & 171,3 & 16,9 & 209,3 & 12,2 & 245,3 & 10,1 & 167,3 & 10,2 \\
\hline Sum & 481,2 & 47,5 & 1052,3 & 61,4 & 1650,8 & 67,9 & 1173,5 & 71,6 \\
\hline In total & 1014,0 & 100,0 & 1804,0 & 100,0 & 2425,9 & 100,0 & 1640,8 & 100,0 \\
\hline
\end{tabular}

Source: based on $[12,302]$.

Table 4

Allocation of labor migrants according to Russia regions

\begin{tabular}{|l|c|c|c|c|c|c|c|c|}
\hline \multirow{2}{*}{ Region } & \multicolumn{2}{c|}{2006} & \multicolumn{2}{c|}{$\mathbf{2 0 0 7}$} & \multicolumn{2}{c|}{$\mathbf{2 0 0 8}$} & \multicolumn{2}{c|}{$\mathbf{2 0 1 0}$} \\
\cline { 2 - 9 } & persons & \% & persons & \% & persons & \% & persons & \% \\
\hline Moscow & 355533 & 35,1 & 532311 & 29,5 & 623160 & 25,7 & 345142 & 21,0 \\
\hline St. Petersburg & 34811 & 3,4 & 163449 & 9,1 & 115398 & 4,8 & 120875 & 7,4 \\
\hline Sverdlovsk region & 52845 & 5,2 & 11061 & 0,6 & 109167 & 4,5 & 82969 & 5,1 \\
\hline Sum & 443189 & 43,7 & 706821 & 39,2 & 847725 & 34,9 & 548986 & 33,5 \\
\hline
\end{tabular}

Source: based on [12, c. 305-307].

is characterized by large inflow of migrants from CIS states (see fig. 1) in connection with liberalization of migration policy; therefore, we infer that this period rather exactly reflects its consequences and data, corresponding to this time interval, can be successfully applied to the calibration of the dynamic multiregional migration model. Reduction in the number of quotas for the issue of work permits since 2008-2010 has led to decrease in a number of registered labor migrants and growth of level of illegal labor migration in Russia for this reason, data of the next years for model calibration was not used.
In consequence of model calibration, the values of the calibration factor for host regions have been received: 0,0295 (Moscow), 0,0885 (St. Petersburg) and 0,1056 (Sverdlovsk region). Accuracy of the model from the absolute value of migration flows is $95 \%$. Consequently, at making a decision about migration, indeed an individual seeks to maximize an expected income according to a wage gap in a host region and a source country at minimization of expenses of moving including an influence of migratory networks, and the offered dynamic model of labour migration is applicable for forecasting of labor migration flows to Russia regions from CIS states.

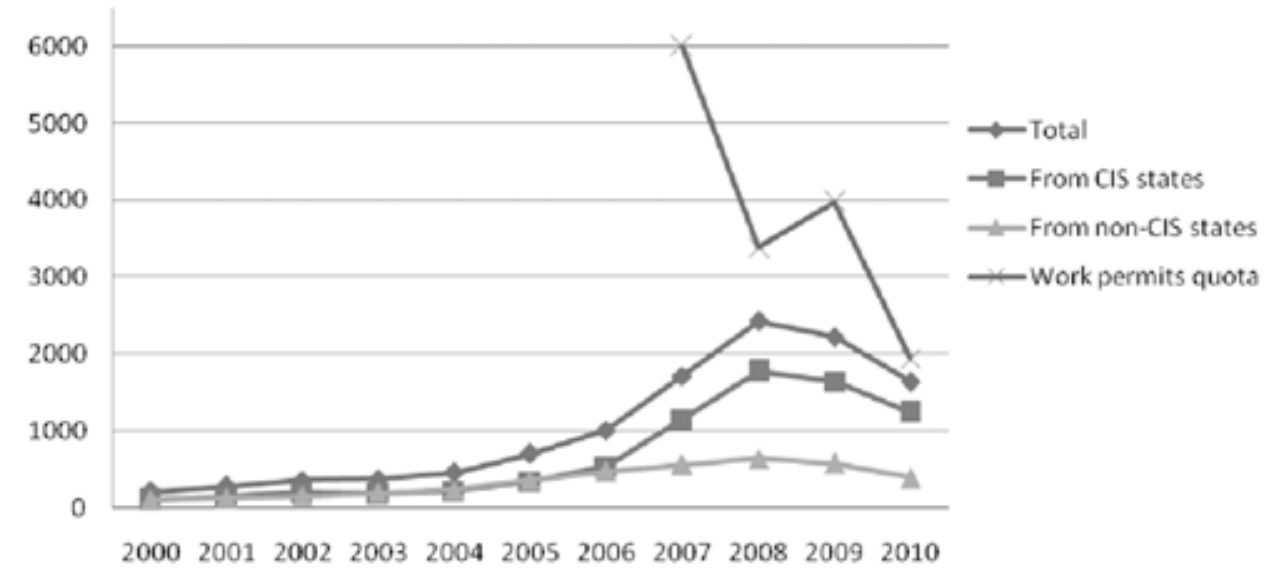

Fig. 1. Origin Composition of Foreign Labor Force in Russia, thousand persons (based on [2, 8]) 


\section{Forecast trajectories of migration flows to Russia}

Employing the model to statistical data, forecast trajectories of migration flows to Russian regions from CIS states have been received for the period since 2010 to 2016. Long-range plan composition of labor migrants in Moscow and St. Petersburg has similarity - the maximum part will be composed by natives of Uzbekistan (fig. 2, 3). However, this composition not long will remain: migrants from Ukraine become dominating on a labor market of Moscow by 2014, in St. Petersburg - by 2012 that is caused by the greatest number of potential migrants [13] and geographic proximity of Ukraine and these host centers of labor. It should be noted that in resulting of reorientation of migration flows observed in recent years from the western CIS states towards Europe, the real inflow of labor migrants from Ukraine can be slightly lower than the predicted.

Common value of foreign labour force will reach 700 thousand people in Moscow by 2016 (fig. 2).

In St. Petersburg common value of foreign labor force will be 580 thousand people by 2016 (fig. 3).

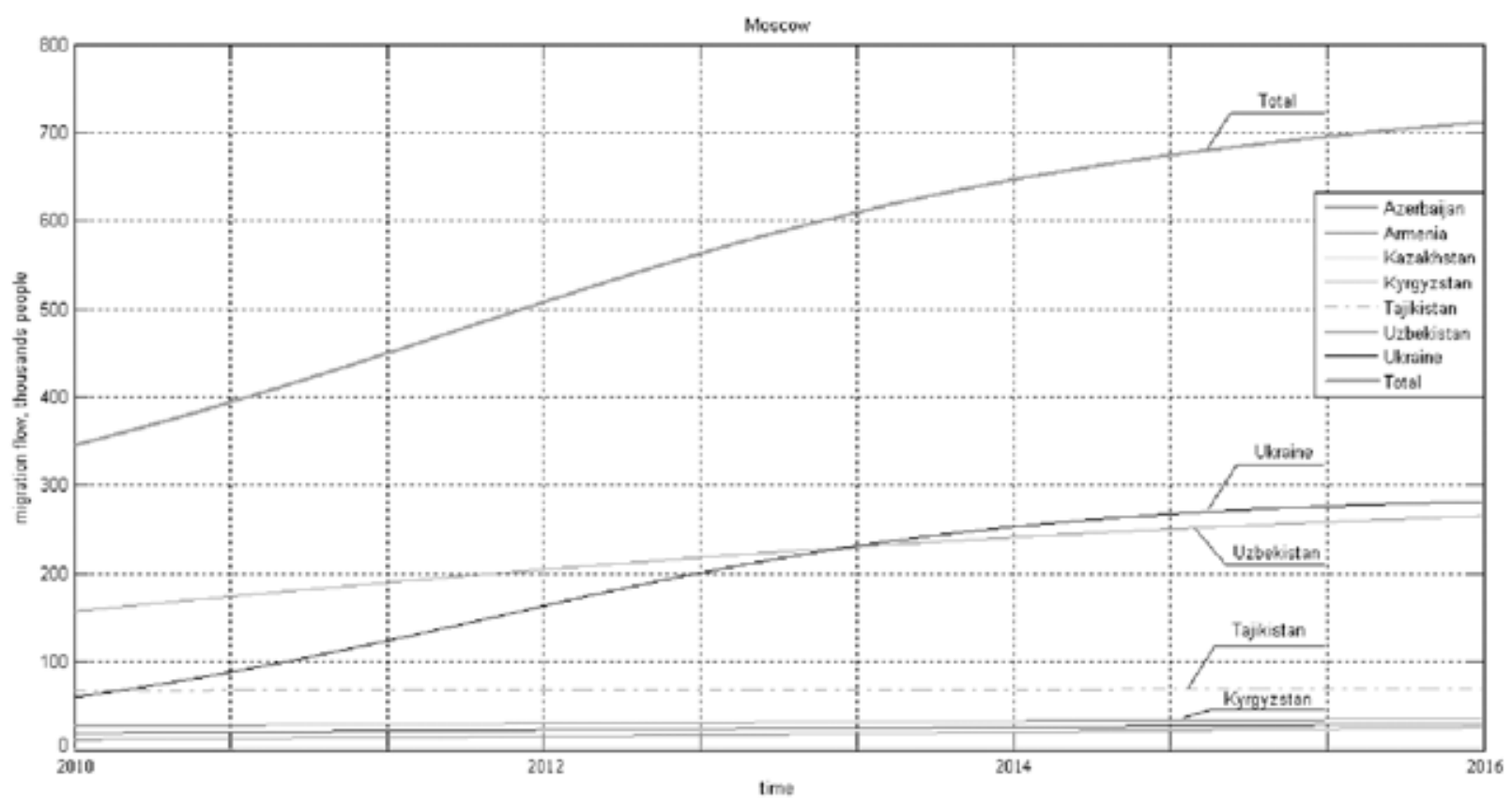

Fig. 2. Migration Flows to Moscow

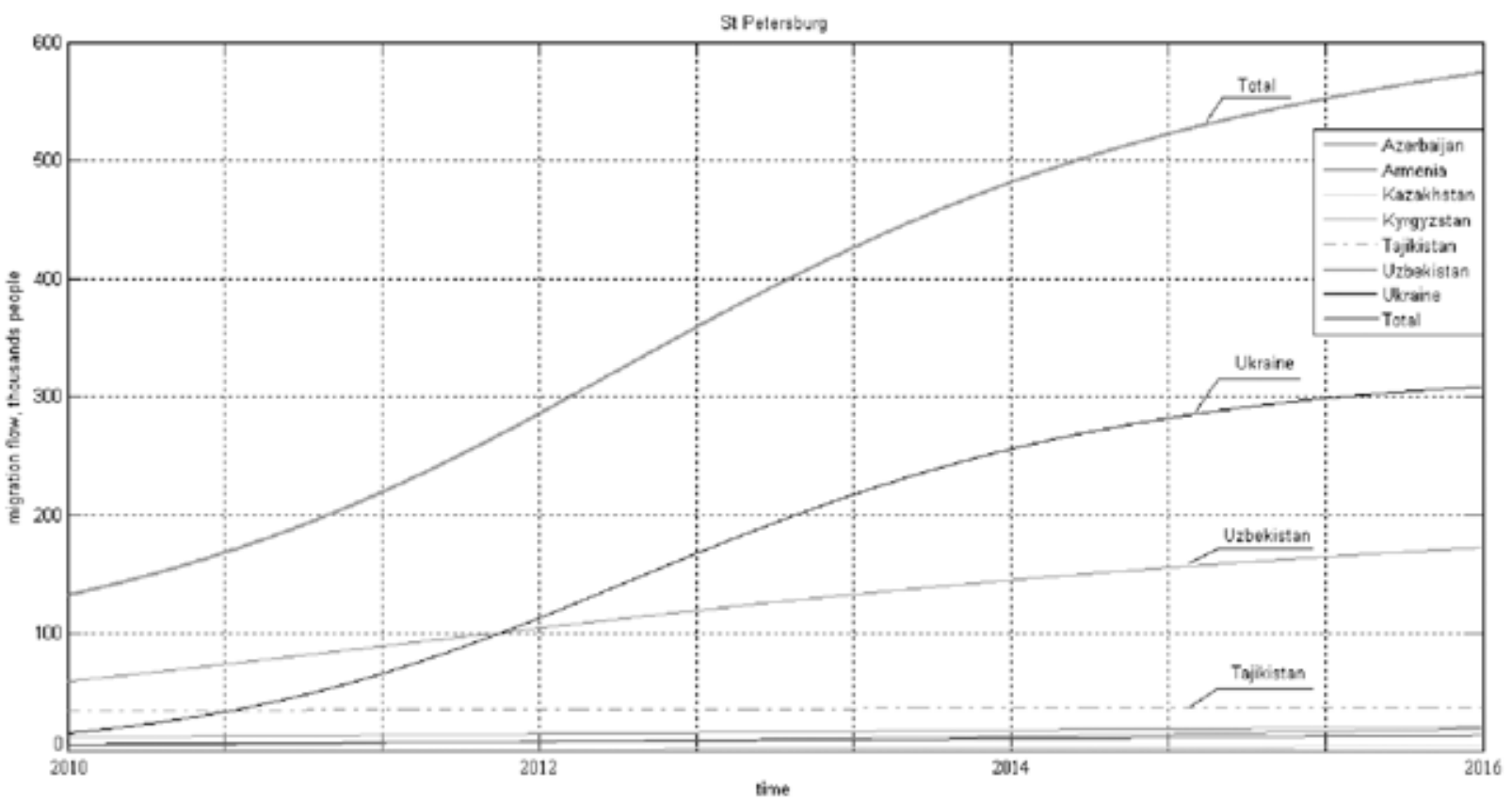

Fig. 3. Migration Flows to St. Petersburg 


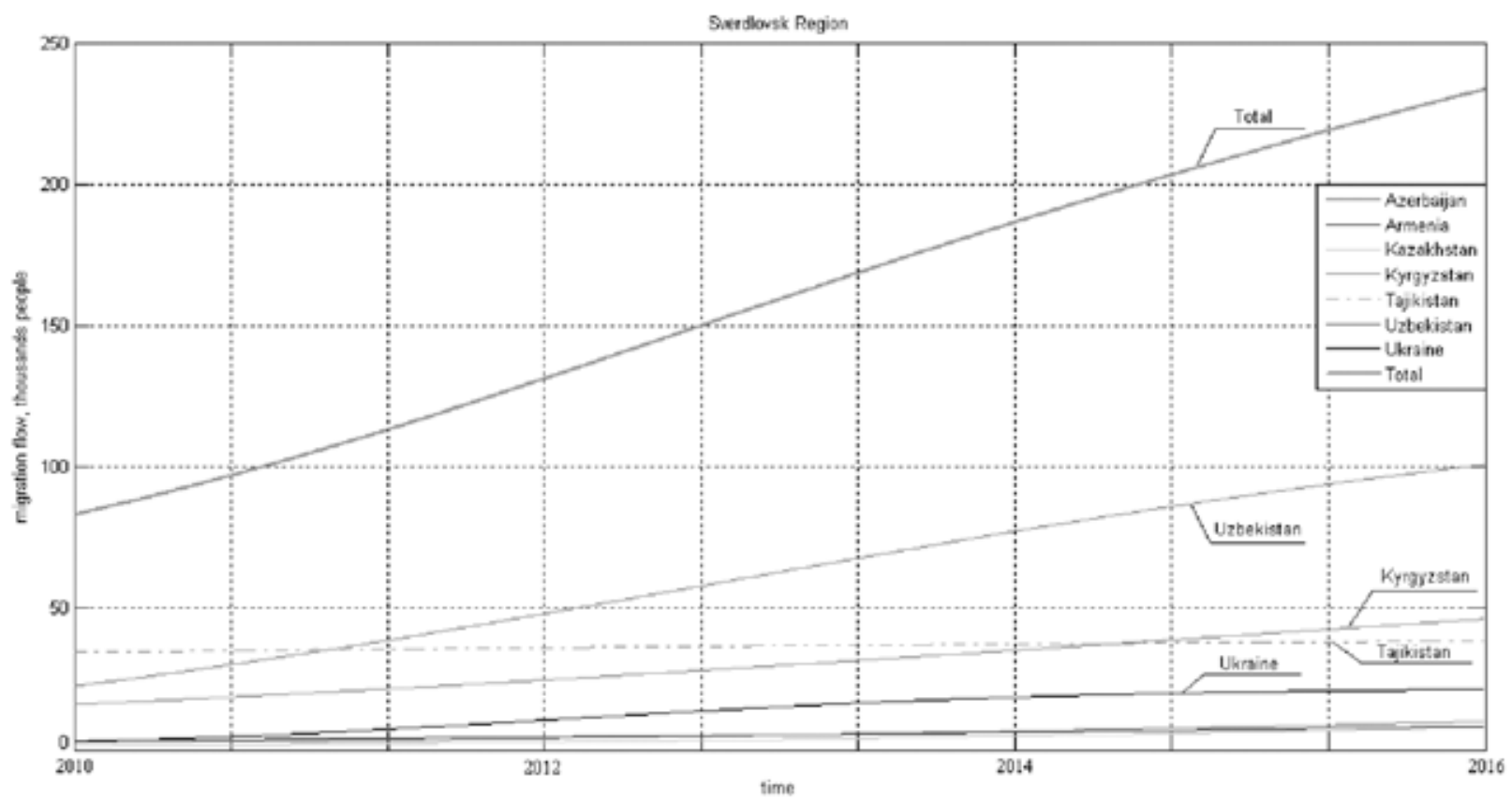

Fig. 4. Migration Flows to Sverdlovsk Region

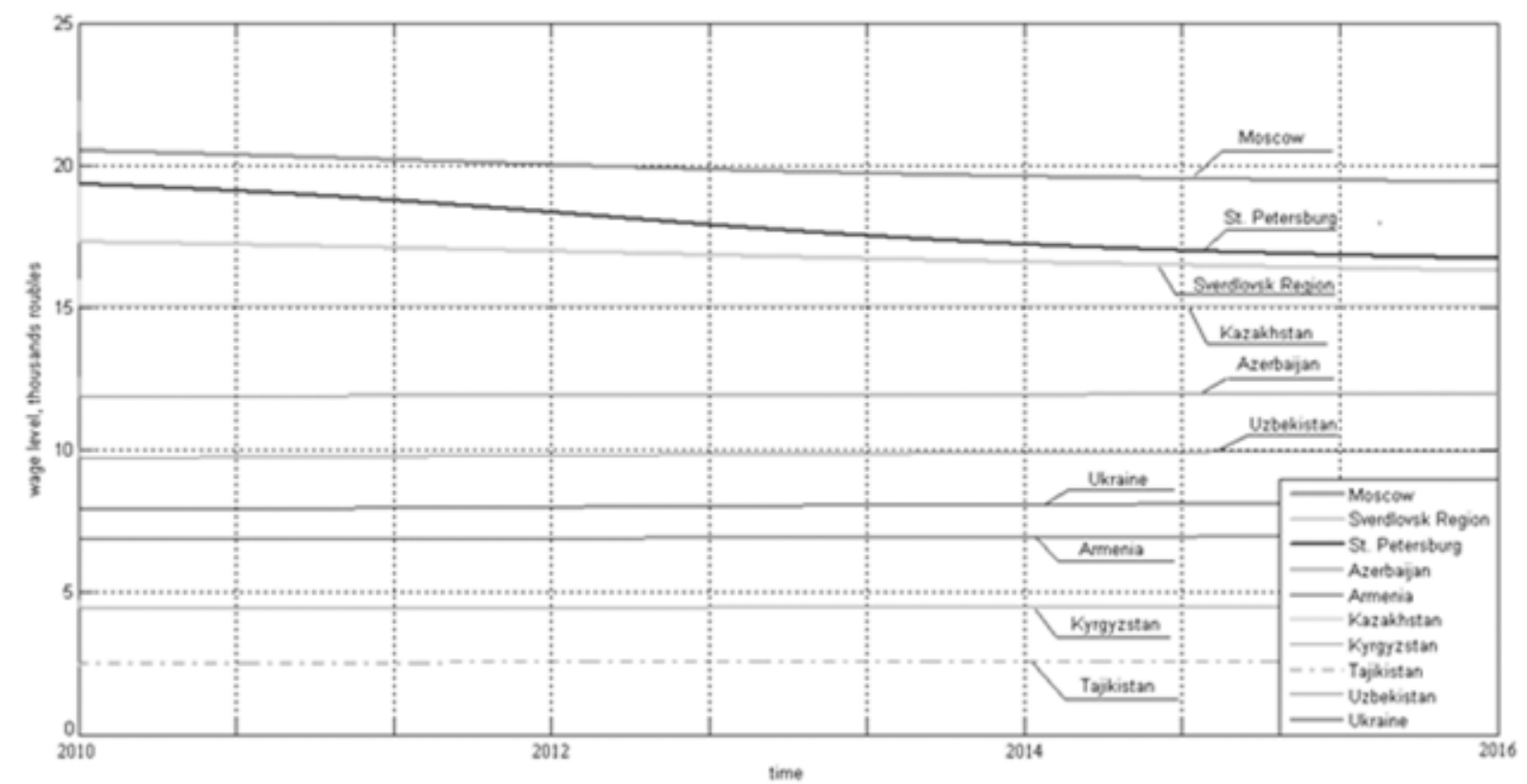

Fig. 5. Wage Level

By reason of geographic proximity of Sverdlovsk region and Central Asia, the origin composition of foreign labor force in Sverdlovsk region will differ from earlier considered regions (fig. 4). Uzbekistan is distinguished among other countries of Central Asia by the greatest number of potential migrants [13] becomes the leading country of departure of migrants. The total number of foreign laborers in Sverdlovsk region will be 230 thousand people by 2016.

Difference in wage level between countries of origin and the accepting regions, conditioning dy- namics of number and composition of migrants, are presented in figure 5. According to the received results, influence of migration on level of a wage generally in accepting regions will be visible.

As a result of economic growth of Azerbaijan and Kazakhstan in which wage levels are the highest among the source countries (fig. 5), decrease in migration flows to Russia from these countries is observed. However, emerging economies of Kazakhstan already have become a strong rival of Russia for labor migrants from Central Asia (first of all, natives of Uzbekistan). 


\section{Conclusions and recommendations}

On the basis of application of the dynamic multiregional model of labour migration to data of regions of Russia and CIS states, possible consequences of liberalization of migration policy in Russia were analyzed. The received forecasts appear rather realistic and have practical relevance. In particular, due to lack reliable methods of calculation of demand for foreign labor force, the offered forecast of the labor migrant flows can be used at the formation of quotas of delivery to foreign citizens of work permits. In point of fact, small quotas for "visa-free" migrants from CIS states instead of actualizing the priority right of the Russian citizens for work, promote growth of illegal employment of foreign citizens in Russia.

The dynamic multiregional model of labour migration has potential of further development, at least, according to three directions. Firstly, account must be taken of migratory expenses. Secondly, function of a wage should consider elasticity between wage and offer of foreign labor force. Thirdly, it is necessary to enter the classification of migrants by the qualified groups. The listed directions of developments of the model will be realized within a framework of further researches of authors.

\section{References}

1. Agarkov G. A., Naydenov A. S., Chusova A. E. (2010). Dinamika tenevogo sektora ekonomiki pod vozdeystviem globalizatsii i nauchno-tekhnicheskogo progressa [Dynamics of the shadow economy under the influence of globalization and scientific-technological progress]. Zhurnal ekonomicheskoy teorii [The economic theory magazine]. 4, 7-17.

2. Arkhiv banka dokumentov sayta Minzdravsotsrazvitiya Rossii [Bank archive of web documents of the Ministry of Health Care and Social Development of the Russian Federation]. Ministerstvo zdravoohraneniya i socialnogo razvitiya RF [Ministry of Health Care and Social Development of the Russian Federation]. Elektronyy resurs [Electronic resource], URL: http://www. minzdravsoc.ru/docs/ (accessed on 20.07.2012).

3. Batishchev G. A. (2011). Migratsionnye protsessy v Rossii kak factor ustoychivogo razvitiya ekonomiki regionov: avtoref. des ... doc. nauk [Migration processes in Russia as a factor of a sustainable development of economy of regions. Synopsis of a thesis, Doctor of Science. Economics]. Rostov on Don, 2011, 55.

4. Vasilyev E. V. (2010). Mezhregionalnaya differentsiatsiya kachestva zhizni naseleniya Rossii [Interregional differentiation of life quality of Russian population]. Ekonomika regiona [Economy of region]. 4, 234-242.

5. Vseobshchaya dekloratsiya prav cheloveka (prinyata Generalnoy Assambleey OON 10.12.1948) [The Universal Declaration of Human Rights (adopted by the United Nations General Assembly on 10.12.1948)]. Elektronnyy resurs. Dostup iz sprav.-pravovoy sistemy «Konsultant plyus» [Web resource. Acceess from ConsultantPlus, information and legal services].

6. Gurban I. A., Myzin A. L. (2011). Teoretiko-metodologicheskiy podhod k otsenke sostoyaniya chelovecheskogo kapitala regionov Rossii [Theoretic and methodologic approach to an assessment of human capital condition of regions of Russia]. Zhurnal ekonomicheskoy teorii [The economic theory magazine]. 2, 21-31.

7. Vishnevskiy A. G., Bobylev S. N. and others. Doklad o razvitii chelovecheskogo potentsiala v Rossiyskoy Federatsii za 2008 god «Rossiya pered litsom demograficheskih vyzovov» [The report on human development in the Russian Federation for 2008 « Russia in the face of demographic challenges »]. Msocw: PROON [UNDP]. 208.

8. Kuklin A. A., Cherepanova A. V., Tarasev A. A. (2012). Modelirovaniye potokov trudovyh migrantov v region. (Na primere Sverdlovskoy oblasti) [Modeling of flows of labor migrants into a region. (On an example of Sverdlovsk region)]. Uroven zhizni naseleniya regionov Rossii [Living standards of the population of Russia regions]. 3, 79-86.

9. Sodruzhestvo Nezavisimyh Gosudarstv v 2010 godu. Statisticheskiy ezhegodnik [The Commonwealth of Independent States in 2010. Annual Abstract of Statistics]. (2011). Mezhgosudarstvennyy statisticheskiy komitet SNG [Interstate Statistical Committee of Independent States]. Moscow, 592.

10. Myzin A. L., Kozitsin A. A., Pyhov P. A. and others. (2006). Sostoyaniye i dinamika izmeneniya urovnya regionalnoy energeticheskoy bezopasnosti [Condition and dynamics of change of level of regional energy security.]. Ekonomika regiona [The economy of region]. 4, 23-36.

11. Strielkovski V., Turnovets F. (2011). Neoklassicheskaya model rabochey sily mezhdu dvumya stranami. Kontseptsiya sklonnosti k migratsii raskhodov [Neoclassical model of mobility of labor force between two countries. Concepts of tendency to migration and indicator of migratory expenses]. Ekonomika i upravleniye [Economy and management] 8(70), 3-9.

12. Trud i zanyatost v Rossii. 2011: sbornik statey [Work and employment in Russia. collection of scientific articles]. (2011). Federalnaya sluzhba gosudarstvennoy statistiki [Federal State Statistics Service]. Moscow, 637.

13. 70 Million in CIS Would Migrate Temporarily for Work // Gallup. [Electronic resource]. URL: http://www.gallup.com/ poll/141746/Million-CIS-Migrate-Temporarily-Work-Study.aspxPI (date access 20.07.2012).

14. Borjas G. J. The Analytics of the Wage Effect of Immigration // NBER Working Paper. — 2009. — №14796.

15. Borjas G. J. The labour demand curve is downward sloping: Reexamining the impact of immigration on the labour market // The Quarterly Journal of Economics. — 2003. — №4(118). - C. 1335-1374.

16. Dustmann C., Preston I. Estimating the Effect of Immigration on Wages // Northface Migration, Discussion Paper. - 2011. - №26.

17. Fasani F. Deporting undocumented immigrants. The role of labor demand shocks. Mimeo. - London :University College London, 2009.

18. Hollifield J. F. Immigrants, Markets and States. The Political Economy of Postwar Europe. — London, 1992. 
19. Longhi S., Nijkamp P., Poot J. A meta-analytic assessment of the effect of immigration on wages // Journal of Economic Surveys. - 2005. - №19(3). - C. 451-477.

20. Longhi S., Nijkamp P., Poot J. Meta-analysis of empirical evidence on the labor market impacts of immigration // IZA discussion paper. - 2008. - №3418.

21. Longhi S., Nijkamp P., Poot J. The impact of immigration on the employment of natives in regional labour markets. A metaanalysis // IZA discussion paper. — 2006. — №2044.

22. Ottaviano G. I. P., Peri G. Immigration and National Wages: Clarifying the Theory and the Empirics // NBER Working Paper. - 2008. — №14188.

23. Ottaviano G. I. P., Peri G. Rethinking the Effects of Immigration on Wages // NBER Working Paper. — 2006. — №12497.

24. Social capital and international migration: a test using information on family networks / Palloni A., Massey D. et al. // The American Journal of Sociology. — 2001. — №106. C. 1262-1298.

\section{Information about the authors}

Vasilyeva Aleksandra Vladimirovna (Yekaterinburg, Russia) - PhD in Economics, research associate at the Center for economic security, Institute of Economics, Ural Branch of the Russian Academy of Sciences (620014, Yekaterinburg, Moskovskaya st., 29, e-mail: sa840sha@mail.ru).

Tarasyev Aleksandr Aleksandrovich (Yekaterinburg, Russia) - economist at the Center for economic security, Institute of Economics, Ural Branch of the Russian Academy of Sciences (620014, Yekaterinburg, Moskovskaya st., 29, e-mail: alextarassiev@ mail.ru). 